Başoğlu, N., Kaplan, T. ve Okur, A. (2014). İlköğretim birinci kademede sözcük öğretimi ile ilgili çalışmaların incelenmesi. Ana Dili Eğitimi Dergisi, 2(4), 50-65.

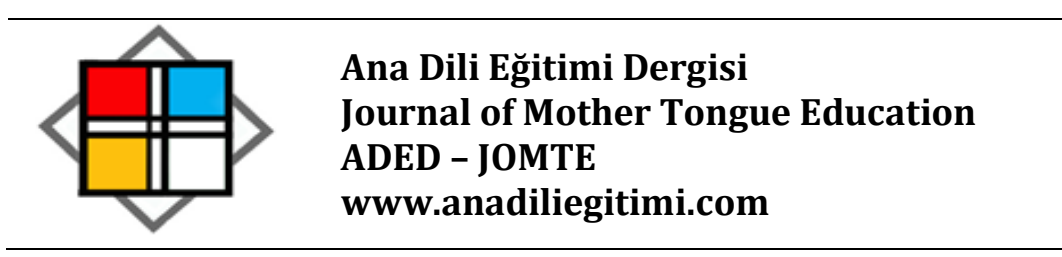

\title{
İlköğretim Birinci Kademede Sözcük Öğretimi İle İlgili Çalışmaların İncelenmesi
}

\author{
Nuran Başoğlu* \\ Tuba Kaplan $^{* *}$ \\ Alpaslan Okur ${ }^{* * *}$
}

Özet

Araştırmanın amacı ilköğretim birinci kademede sözcük öğretimiyle ilgili çalışmaların benzer ve farklı özelliklerini belirlemek, sonuçlarının Türkçe dersi için sözcük öğretimine katkılarını incelemek ve çalışmalarda yoğun olarak işlenen başıkları saptamaktır. Tarama modelinin kullanıldığı ve doküman incelemesi yapılarak verilerin toplandığı bu araştırmanın örneklemini ilköğretim birinci kademede yapılan sözcük öğretimiyle ilgili çalışmalar oluşturmaktadır. Sonuç olarak, ilköğretim birinci kademede sözcük öğretimi ile ilgili olarak tespit edilen ve betimsel yolla analizi yapılan toplam 62 çalışma altı alt başlıkta incelenmiştir. Ders kitapları ve metinler üzerine 15 çalışma; uygulamanın esas olduğu 14 çalışma; teorik bilgi veren 13 çalışma; yazılı anlatımdaki aktif kelime servetini belirlemeye yönelik 16 çalışma; sözlü anlatımdaki aktif kelime servetini belirlemeye yönelik 1 çalışma; öğretmenler üzerine yapılan 3 çalışma tespit edilmiştir.

Anahtar Sözcükler: sözcük öğretimi, birinci kademe, söz varlığı.

\section{Examination of Studies About Vocabulary Teaching in Primary School}

\begin{abstract}
The aim of the research is determining similarities and differences of the studies in the field of teaching word in primary school, examining how much the results of the study contribute to teaching word for Turkish lesson and determining the topics that have been focused intensely. The sample of this research in which scanning model was applied and data was gathered through document investigation consisted of studies on word instruction in primary stage. As a result, 62 studies in the total which were established about word instruction in the primary stage of primary education and analyzed descriptively were examined under six sub-headings. 15 studies on course books and texts; 14 practice-based studies; 13 studies which gives theoretical knowledge; 16 studies presenting active word wealth in written expression; 1 study presenting active word wealth in oral expression; 3 studies on teachers were identified.
\end{abstract}

Key Words: word instruction, primary stage, word wealth.

\footnotetext{
* Okt. Nuran Başoğlu, Bülent Ecevit Üniversitesi, Ereğli Eğitim Fakültesi, Türkçe Eğitimi Bölümü, Zonguldak, nuranbasoglu@hotmail.com

** Okt. Tuba Kaplan, Gaziantep Üniversitesi, TÖMER, Gaziantep, tubakaplan@gantep.edu.tr

${ }^{* * *}$ Doç. Dr. Alpaslan Okur, Sakarya Üniversitesi, Eğitim Fakültesi, Türkçe Öğretmenliği Bölümü, Sakarya, aokur@sakarya.edu.tr
} 


\section{Giriş}

Sözcük öğretiminde bireyin içinde bulunduğu yaş ve eğitim düzeyi önem taşımaktadır. 7-11 yaşları arası çocukluk dönemidir. Bu dönemde çocuk dünyayı benmerkezci ve sihirsel açıdan algılama ve düşünmeyi bırakıp, daha somut ve sistemli düşünmeye başlar (Ergün, 2014). Piaget (1969)'nin "Somut İşlemler Dönemi" olarak tanımladığı bu dönemde sınıflandırma, sıraya koyma gibi üst düzey düşünme becerileri gelişen çocuklar, sebep-sonuç ilişkilerini anlayabilirler. Bu anlamda okul çağı diye nitelendirebileceğimiz 7-11 yaş dönemi, çocuğun öğrendiği sözcükleri kullanması açısından oldukça verimli bir dönemi ifade eder.

Yapılan araştırmalarda çocukların büyük bir çoğunluğunun, dil edinme sürecinin önemli bir bölümünü, 5-6 yaşlarına kadar edindiği, dili ustaca kullanabilme becerilerini ise 5-10 yaşları arasında edindiği kabul edilmektedir (Yapıcı, 2004). 7-8 yaşından önce çocuklar aralarında ne nedene dayanan açıklamada bulunur; ne de delil gösterir. Bunları düşünse bile, dilinin henüz benmerkezci olması yüzünden anlatamaz (Piaget, 1969). Okul çağında sözcük öğretiminde başarının sağlanması için dört temel dil becerisi açısından öğrencinin gelişim özellikleri incelendiğinde özellikle okuma-yazma öğrenimi ile beraber çocuğun dil gelişiminin de hızlı bir ilerleme gösterdiği görülmektedir.

7 yaşındaki çocuk, yazı yazmaktan hoşlanır. Harfleri bu yaşta daha önceki yaşa nazaran daha küçük ve düzenli yazar. 8 yaşındaki çocuklar adreslerini bilirler; fakat imla yönünden sorunları vardır. Kısaltmaları ve kelimelerin baş harflerini yazarken hata yaparlar fakat okumada daha başarılı hâle gelir ve okurken anlamı kaybetmezler. 9 yaş ise çocukların çoğu açısından bağımsız bir şekilde sessiz okumanın ilk yaşıdır (Akyol, 2006: 37-39). 8-10 yaşlarında çocuklar, duygu ve düşüncelerini beş-on kelimeden oluşan cümlelerle anlatabilir; konuşma ve yazılarını benzetme ve deyimlerle zenginleştirebilirken 10-12 yaş ve üstü dönemlerde, olumluluk ve olumsuzluk bildiren yan cümleler kullanarak, yargılarını oluştururlar (Tuncer, 2007:127).

Millî Eğitim Bakanlığı 1-5.sınıflar Türkçe öğretim programında (2006); Türkçeyi doğru ve etkili kullanan, kendini ifade eden, iletişim kuran, işbirliği yapan, girişimci ve sorun çözen, okumaktan ve öğrenmekten zevk alan ifadeleri ile programın vizyonu açıklanmaktadır. Vurgulanan özellikler bireyin söz varlığı ve bu söz varlığını kullanımı ile doğrudan ilişkilidir. Programın öğrenme alanlarında ise; kelimelerin doğru tanınmamasının cümlelerin, paragrafların ve giderek bütün metnin yanlı̧ anlaşılmasına neden olduğu; bu nedenle kelime çalışmalarına gereken önem verilmesi ve öğrencinin söz varlığının geliştirilmesi gerektiğine dikkat çekilmektedir. IIlköğretim birinci kademe Türkçe öğretim programı ile çerçevesi çizilen bu durum ders kitapları ile somut bir hâl almaktadır. Ders kitapları hazırlanırken öğrencilerin dil gelişimine uygun olarak sözcüklerin somut-soyut, yalın-karmaşık, az kullanılır-çok kullanılır olma durumlarına dikkat edilmelidir. Ders kitapları aracılığıyla sözcük evrenini genişletmek için öğrencilerin yaş ve düzeylerine uygun çalışmalara yer verilemesi gerekir. Bu çalışmada bahsedilen hususlar göz önünde bulundurularak taranan çalışmalar incelenecektir. 


\section{Yöntem}

Bu araştırmanın amacı; ilköğretim birinci kademede sözcük öğretimiyle ilgili çalışmaların benzer ve farklı özelliklerini belirlemek, sonuçlarının Türkçe dersi için sözcük öğretimine katkılarını incelemek ve çalışmalarda yoğun olarak işlenen başlıkları saptamaktır. Araştırmada tarama modeli kullanılmıştır. Tarama modelinde geçmişte ya da hâlen var olan durumu olduğu gibi betimlemek amaçlanmaktadır. Onları değiştirmek gibi bir amaç yoktur ve önemli olan onu iyi bir şekilde gözleyip belirlemektir (Karasar, 2010: 77).

Araştırmada taranan çalışmanın kapsamı YÖK'te erişime açık bulunan tezler ve ULAKBiM'de taranan makaleler ve basımına ulaşılabilen kitaplar ile sınırlandırılmıştır. Araştırmanın evrenini sözcük öğretimi ile ilgili çalışmalar, örneklemini ise ilköğretim birinci kademede sözcük öğretimiyle ilgili çalışmalar oluşturmaktadır. Örneklem olarak kabul edilen 62 çalışmanın; 30 tanesi tez (26 tanesi yüksek lisans ve 4 tanesi doktora tezi), 27 tanesi makale ve 5 tanesi kitaptır.

Doküman incelemesi yoluyla toplanan veriler betimsel olarak analiz edilmiştir. Bu yaklaşıma göre, elde edilen veriler, daha önceden belirlenen temalara göre özetlenir ve yorumlanır (Yıldırım ve Şimşek, 2011: 224). Verilerin analizini yapmak amacıyla öncelikle ilköğretim birinci kademede sözcük öğretimi ile ilgili yapılan çalışmalar detaylı bir şekilde incelenmiş, ardından yapılan çalışmaların benzerlikleri ve farklııkları "Ders Kitapları/Metinler Üzerine Yapılan Çalışmalar, Uygulamanın Esas Olduğu Çalışmalar, Yazılı Anlatımdaki Aktif Kelime Servetini Belirlemeye Yönelik Çalışmalar, Sözlü Anlatımdaki Aktif Kelime Servetini Belirlemeye Yönelik Çalışmalar, Öğretmenler Üzerine Yapılan Çalışmalar, Teorik Bilgi Veren Çalışmalar" başlıkları altında incelenmiştir.

\section{Bulgular}

\section{Ders Kitapları/Metinler Üzerine Yapılan Çalışmalar}

Ders kitapları Türkçe öğretiminin vazgeçilmez araçlarındandır. Öğretmenin derste takip edeceği konular belli bir sistem içerisinde kitaplarda yer alır. Bu nedenle ders kitapları öğretmenlerin en büyük yardımcılarındandır. Illköğretim birinci kademede sözcük öğretimiyle ilgili çalışmalara bakıldığı zaman ders kitapları ve kitapların içindeki metinler üzerine çokça çalışmaya yer verildiği görülmektedir.

Karadağ (2005), öğrencilerin yaygın olarak kullandıkları kelimelerle ders kitaplarındaki kelime sıklık listelerini karşılaştırdığı araştırma sonucunda; öğrencilerin sık kullanmalarına rağmen ilgili kelimelerin ders kitaplarında yer almadığını tespit etmiştir. Baş (2006) ise, öğrencilerin kelime hazinesiyle kitaplarda geçen kelimeler arasında uyum olmadığını belirtmiştir. İpek Eğilmez (2010) ilköğretim dördüncü sınıf öğrencilerinin yazılı anlatımları ile bu öğrencilere okutulmak üzere MEB 
tarafından hazırlanan ilköğretim dördüncü sınıf Türkçe ders kitabında yer alan metinleri söz varlığı açısından incelemiştir. Ders kitabı ile öğrencilerin yazılı anlatımları arasındaki karşılaştırmada ders kitabının sözcük, ikileme ve deyim kullanma açısından öğrencilere oranla daha ileri düzeyde olduğu; bunun yanı sıra ders kitabında hiç atasözü kullanılmadığı sonucuna ulaşmıs ve ayrıca öğrencilerin yazılı anlatımlarında ve ders kitabında ortak kullanılan sözcüklerin, toplam sözcüklerin \%37'sini oluşturduğunu tespit etmiştir.

Karadağ ve Kurudayığlu (2010a), 1. ve 5. sınıf ders kitaplarını düzeylere göre incelemişler, yürürlükten kaldırılan ders kitapları ile yürürlükteki ders kitaplarını karşılaştırarak ortak ve farklı kelimeleri tespit etmişlerdir. Özkök Kayhan (2010), Türkçe ders kitaplarında yer alan kelimelerin ders kitaplarında sık geçen kelimeler olduğu sonucuna ulaşmıştır. Anılan, Genç ve Dede (2011); destekleyici metinlerin, öğrencilerin kelime edinimlerini olumlu etkilediği ve batı kırsalında eğitim gören öğrencilerin kelime bilgilerinin daha yüksek olduğu sonucuna ulaşmışlardır.

Keklik (2011a), 7-11 yaş grubu arasındaki çocuklara öğretilmesi gereken 1800 kelimeyi belirlemeyi amaçlamıştır. Türkçe dışında başka dillerdeki kaynaklardan da faydalanılan çalışma sonucunda belirlenen kelime listesine yer verilmiştir.

Pehlivan (2003), ders kitaplarında sözcük öğretimiyle ilgili çalışmalarda sözcüklerin anlam, kullanım ve yazımlarıyla ilgili pekiştirme çalışmalarına yer verilmediği sonucuna ulaşmıştır. Mangır (2012), Illköğretim Türkçe 5 Ders Kitabı'nda deyimlerin metinler içinde orantılı bir şekilde yer almadığını, deyim kullanımının yaş seviyelerine göre fazla olduğunu ve öğretilmesi hedeflenen deyimlerle ilgili tekrarın ve alıştırmanın yeterli olmadığını ortaya koymuştur. Akyüz Aru (2013), ilköğretim 1-4. sınıf Türkçe ders kitaplarındaki metinlerde yer alan ve kazandırılması istenen kelimelerin öğretiminde sistemli bir yol izlenmediğini tespit etmiştir. Gür, Coşkun ve Sağlam (2013), ilkokul 2, 3 ve 4. sınıflarda okutulan özel yayın evlerine ait Türkçe ders kitaplarındaki kelimeleri inceledikleri araştırma sonucunda sınıf seviyelerine göre kelime kullanımlarında artış olduğunu; ancak farklı sınıflarda kelime tekrarına gidildiğini tespit etmiştir.

Solmaz (2009), ilköğretim 4 ve 5. sınıf Türkçe ders kitaplarında yer alan metinlerdeki kelime hazinesinin okunabilirlik durumunu olumlu etkilediğini tespit etmiştir. Özalp (2011), 2008-2009 ve 2009-2010 eğitim öğretim yılında Milli Eğitim Bakanlığı baskılı Türkçe ders kitaplarında şiir dışındaki metinlerin kelime sayısı ve kelime hazinesini artırmaya yönelik olup olmadığını incelemiş ve yapılması gerekenler hakkında bilgi vermiştir. Yalçın (2005), 1. ve 5. sınıf Türkçe ders kitaplarındaki kelimelerin niteliklerini incelediği araştırmanın sonucunda; kitaplardaki metinlerin öğrencilerin zihinsel gelişim sürecine ve öğretim ilkelerine uygun olmadığını tespit etmiştir. Aslan (2006), ilköğretim 1,2,3,4 ve 5 . sınıf Türkçe ders kitaplarındaki yabancı sözcüklerin varlığını incelemiş; dilin çevrimine girmesine karşın Türkçe karşılıkları kullanılmayan 43 yabancı sözcüğün bulunduğunu ve ayrıca kitaplarda yazım 
ve noktalama yanlışları olduğunu tespit etmiştir. Türkçenin kendi öz değerlerini yansıtma gibi özel bir görevi ve sorumluluğu olan Türkçe ders kitaplarının bu bakımdan duyarlı ve titiz hazırlanmamasına dikkat çekmiştir.

\section{Uygulamanın Esas Olduğu Çalışmalar}

Eğitim-öğretim sürecinde teorik bilgileri öğretmek ne kadar önemliyse onların uygulanması da aynı derecede önemlidir. Uygulama sürecinde öğretmen öğrenciye yol gösterirken bilgiyi onun keşfetmesini sağlar. Illköğretim birinci kademede Türkçe derslerinde sözcük öğretiminde uygulamanın esas olduğu çalışmalarda sıklıkla; sosyo-ekonomik durum, cinsiyet ve ailenin eğitim düzeyi gibi değişkenler inceleme konusu olarak karşımıza çıkmaktadır.

Davaslıgil (1985), sosyo-ekonomik düzeyi farklı olan iki okuldaki öğrencilerin kelime düzeylerini incelemiş, araştırma sonucunda sosyo-ekonomik düzeyi yüksek olan öğrencilerin kelime hazinesinin daha iyi olduğunu belirlemiştir. Alpöge (1991), üç ve sekiz yaşları arasında sıfatların kullanım durumunu çocukların gelişmesi bakımından incelemiş ve sosyo-ekonomik düzeyin öğrencilerin sıfatları kullanım düzeyini etkilediği sonucuna ulaşmıştır. Pilancı (2014), 7-9 yaş arasındaki Türk çocuklarının 11 üst kavramdaki kelime çağrışımları ve bu çağrışımları etkileyen faktörleri araştırmıştır. İki farklı sosyal çevreden seçilen çocuklara 11 üst kavram altında kelimelerin çağrıştırdıkları sorulmuştur. Araştırma sonucunda 7-9 yaş arasında kuvveti yüksek olan çağrışım sayısının beklenilenin aksine düşük olduğu görülmüştür.

İpek (2006), sosyoekonomik düzeyin öğrencilerin kelime hazinesini etkilediği, kız öğrencilerin kelime dağarcığı ile erkek öğrencilerin kelime dağarcığı arasında ise çok fazla bir fark olmadığı sonucuna ulaşmıştır. İpek ve Bilgin (2007) ise; üst düzey sosyoekonomik düzeydeki öğrencilerin daha başarılı olduğunu, kız öğrencilerle erkek öğrenciler arasında anlamlı bir fark olmadığını, sınıf düzeyinin artmasına bağıı olarak kelime düzeyinin de arttığını tespit etmişlerdir. Pilancı (2009), sosyoekonomik durumun 7-9 yaş arasındaki öğrencilerin kelime hazinesini etkilediği, öğrencilerin kelime hazinelerindeki sözcüklerin tamamını aktif olarak kullanmadıkları sonucuna ulaşmıştır. Keklik (2012), 120 karşıt anlamlı kelimenin kavranma düzeyini belirleyerek yaş, cinsiyet ve öğrencilerin yaşadığı yer açısından incelemiştir. Araştırma sonucunda karşıt anlamlı kelimelerin kavranma düzeyinin cinsiyete göre değişmediği ve öğrencilerin yaşına bağlı olarak arttığı belirlenmiştir.

Acat (2008), çalışmasında kavram haritalarıyla kelime öğretiminin geleneksel yaklaşımdan daha etkili olduğunu belirtmiştir. Lüle Mert (2010), kelime öğretiminde kullanılan etkinliklere, sözcük öğretimi ile ilgili bilgilere ve atasözü ve deyim öğretebilmek amacıyla resimli etkinlik örneklerine yer vermiştir. Çevik (2011), hikâyeler ve görsellerle anlatılan öğrenci gurubunda deyimlerin öğrenilme durumun daha yüksek olduğu sonucuna ulaşmıştır. 
Keklik (2009), Türkçede sık kullanılan 3000 kelimeyi tespit ederek bunların arasından 120 tane karşıt anlamlı kelimenin $6,7,10$ ve 11 yaş grubu öğrencileri tarafından ne derece bilindiğini tespit etmeyi amaçlamıştır. Araştırmada karşıt anlamlı kelimelerin bilinme durumunun yaş seviyesine göre değiştiği, kız öğrencilerin daha çok karşıt anlamlı kelime bildiği; ancak anlamlı bir fark olmadığı, anne ve babaların eğitim durumunun çocuklarının karşıt anlamlı kelime bilme durumunu etkilediği sonuçlarına ulaşmıştır. Tuğyan (2010), kelime servetlerinde fihrist, sözlük ve metin defteri kullanımının etkisinin olup olmadığı araştırmıştır. Araştırma sonucunda; kız öğrencilerin erkek öğrencilere daha düzenli oldukları için kelime hazinelerinin daha zengin olduğu ve fihrist, sözlük ve metin defteri kullanımının öğrencilerin sözcük dağarcığını olumlu etkilediği görülmüştür. Ailenin eğitim düzeyinin ve ekonomik düzeyin öğrencilerin kelime hazinesinde önemli olduğu görülmüştür.

Kazak Berument ve Gül Güven (2013), ülkemizde geniş yaş aralığına yönelik, alıcı dilin kelime bilgisini değerlendirebilecek özgün, güvenilir ve geçerli bir testin bulunmadığını belirterek özgün bir dil testi geliştirmişlerdir.

Karadağ (2013), söz varlığının önemini ve unsurlarını, farklı araştırmacıların görüşlerini değerlendirerek belirginleştirmeye çalışmıştır. Çalışmada Türkçe kelimelerin yapı ve anlam bakımından özellikleri üzerinde durulmuş; çocukta dil gelişimi açıklanarak, kelime öğrenme ve öğretiminin esasları belirlenmeye çalışılmıştır. Uygulama örnekleri kılavuz etkinlikler şeklinde sunulmuş ve öğretmenlerin etkinlik üretmelerine kaynak oluşturması düşünülmüştür.

Uygulamanın esas olduğu çalışmalar sonucunda genel olarak;

- Sosyo-ekonomik düzeyi yüksek olan öğrencilerin kelime hazinesinin daha iyi olduğu,

- Öğrencilerin kelime hazinelerindeki sözcüklerin tamamını aktif olarak kullanmadıkları,

- Sınıf düzeyinin artmasına bağlı olarak kelime düzeyinin de arttığı,

- Kavram haritalarıyla, etkinliklerle, hikâyeler ve görsellerle kelime öğretiminin geleneksel yaklaşımdan daha etkili olduğu,

- Fihrist, sözlük ve metin defteri kullanımının öğrencilerin sözcük dağarcı̆ını olumlu etkilediği,

- Karşıt anlamlı kelimelerin bilinme durumunda; yaş seviyesine göre değişiklik olduğu, anne ve babaların eğitim düzeyinin etkili olduğu, cinsiyete göre ise değişiklik olmadığı tespit edilmiştir. 


\section{Teorik Bilgi Veren Çalışmalar}

Akyol (1997), kelime hazinesinin gelişmesinde önemli bir yeri olan kelime bilgisi seviyeleri, kelime sayısı ve kelime öğretimi üzerinde durarak anlamanın gelişmesinin kelime hazinesiyle alakalı olduğunu belirtmiştir. Tosunoğlu (1999), kelime servetinin öneminden ve bu alanda yapılan çalışmalardan bahsetmiştir. Çeçen (2002), kelime hazinesini geliştirmek hususunun Türkçe eğitiminde önemli bir gündem maddesi hâline getirilmesi gerektiğini vurgulamıştır. Öğrencilerin sözcük dağarcığını geliştirmede dramatizasyon ve televizyonun rolüne değinmiştir. Demir (2006), öğrencilerin kelime hazinesini geliştirmekle ilgili yapılan çalışmaları değerlendirmiş ve çeşitli çözüm önerileri sunmuştur.

Ince (2006), kelime hazinesini geliştirme yolları hakkında bilgi vermiş, kelime ve kelimenin öğretimi, kelime tanıma ve ayırt etme, yapı bakımından kelimeler, anlam bakımından kelimeler, telâffuzları bakımından kelimeler, yazılışları bakımından kelimeler konuları ele almıştır. Akyol ve Temur (2007), Türkçe Öğretim Programı́nda kelime öğretimine yönelik kazanımlar ve öğrenmeöğretme süreçlerini incelemiş ve çeşitli etkinliklere yer vermişlerdir. Özbay ve Melanlıoğlu (2008), kelime hazinesinin önemini vurgulayarak öğrenciye yeni kelimelerin kazandırılması sırasında dikkat edilmesi gereken noktalar ve kelime öğretim yöntemleri üzerinde durmuşlardır. Göçer (2009), kelime hazinesinin önemini vurgulamış, yurt içi ve yurt dışı kaynaklardan kelime öğretimiyle ilgili etkinlik örneklerine yer vermiştir. Lüle Mert (2009), ana dili öğretiminde kelime öğretiminin önemine dikkat çekerek deyimleri kandırmaya yönelik etkinlik örneklerine yer vermiştir.

Baş (2010), kelime öğretiminin belli bir sistem dâhilinde yapıldığı, aynı sınıf seviyesi için hazırlanan kitaplarda kelimeler arasında tutarsızlıklar olduğu ve yapılan çalışmalarda yurt dışı kaynaklarından doğrudan aktarım yapıldığı bunun da tutarsızlıklara neden olduğuna değinmiştir. Duran (2010), Türkçe 1-5. Sınıflar Öğretim Programı́nda kelime hazinesini geliştirmeye yönelik kazanımları, ilk okuma yazma yöntemi, öğrenme-öğretme süreci ve serbest okuma saati uygulamasını incelemiş, ses temelli cümle yönteminin öğrencilerin kelime hazinelerini geliştirici nitelikte olduğunu belirtmiştir. Keklik (2011b), Türk Dil Kurumunun onuncu baskısı olan 2005 basımı Türkçe sözlüğü esas alarak öğretilmesi gereken bin kelimeyi alfabetik olarak sıralamıştır. Güneş (2013), kelime tanıma modelleri, kelime öğretimi ve yaklaşımları, zihinsel sözlük (aktif-pasif), zihnin kelime işleme gücü, kelime öğretme teknikleri gibi konularda bilgi vermiştir.

\section{Yazılı Anlatımdaki Aktif Kelime Servetini Belirlemeye Yönelik Çalışmalar}

Öğrencinin; heyecan, korku, özgüven eksikliği, çevre baskısı gibi unsurlardan dolayı konuşurken kelime hazinesinde bulunan kelimeyi kullanamaması durumuna karşın yazarken bu etkenlerin birçoğundan arınmış bir şekilde kendini ifade etmesi mümkündür. Bu anlamda yazma becerisi sözcük öğretimi çalışmalarında sık başvurulan bir kaynak olarak karşımıza çıkmaktadır. Türkçe 
öğretim programında da yazma becerisi ile ilgili olarak; öğrencilerin yazılarında söz varlığından yararlanmaları; anlamı zenginleştirmek amacıyla deyim, atasözü, özdeyiş vb. kullanmaya özendirilmeleri gerektiği ifadeleri geçmektedir (MEB, 2009).

Sözcük öğretiminin yazma becerisindeki durumunu tespit etmek ve çözüm önerileri sunmak amacıyla çeşitli çalışmalar yapılmıştır. Bu çalışmalardan çoğunun 5. sınıf düzeyinde yoğunlaştığı ve yazılı anlatımdaki aktif kelime servetini ölçmek amacıyla öğrencilere otobiyografi, anı, serbest konu gibi belirli türlerde kompozisyon yazdırıldığı görülmektedir. Bu kompozisyonlardan elde edilen veriler çoğunlukla cinsiyet ve soyso-ekonomik duruma göre yorumlanmıştır. Sözcük öğretimini yazılı anlatım ile ilişkilendiren, ortak bir amaca ve değişkene göre hazırlanan bu çalışmaların (11 tez çalışması) tablo hâlinde sunulması uygun görülmüştür.

Tablo 1: Yazılı Anlatımda Aktif Kelime Servetine Yönelik Çalışmalar

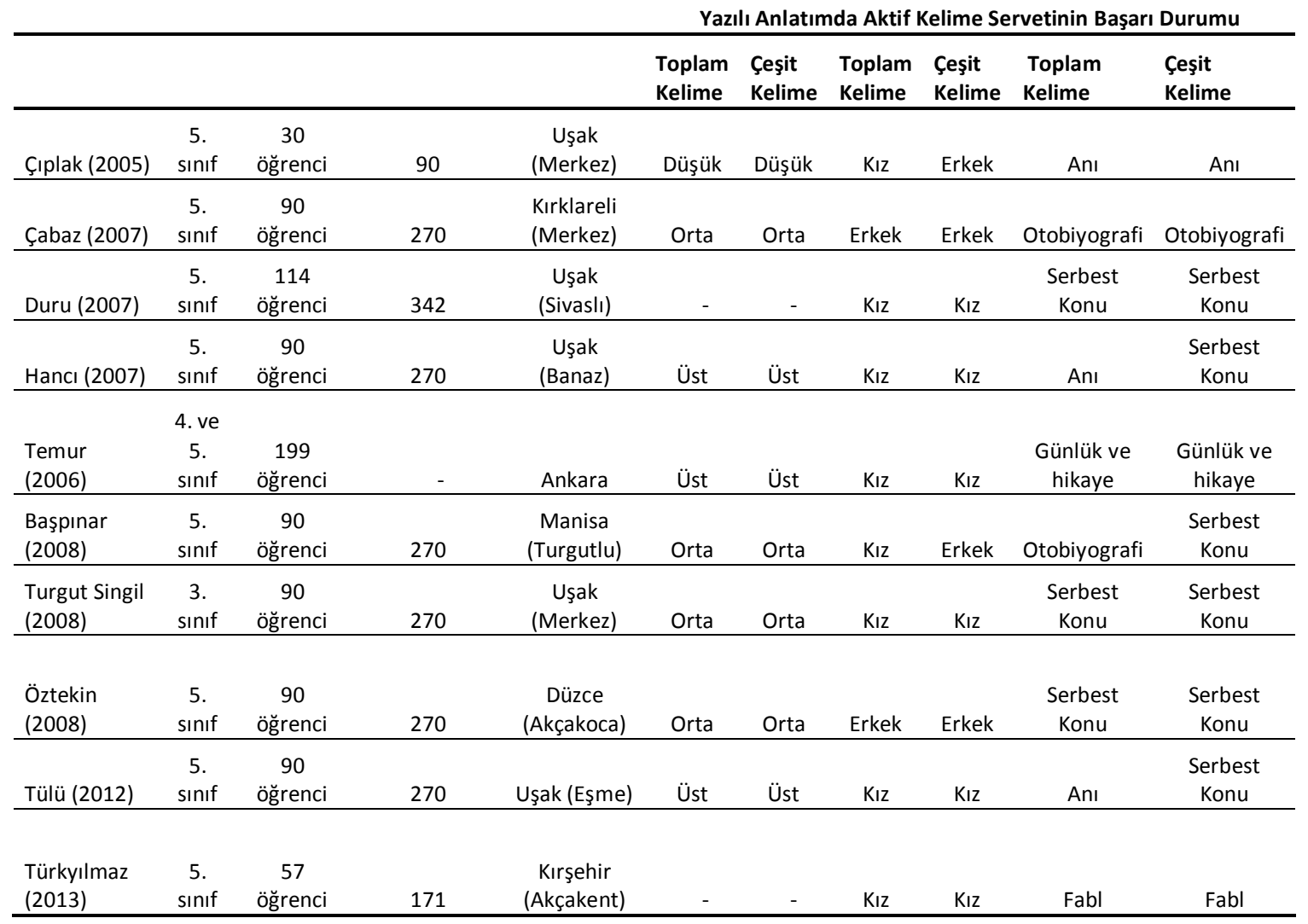

Tablo 1'de yer alan yazılı anlatımda aktif kelime servetini belirlemeye yönelik çalışmalar incelendiğinde; çalışmaların sonuçlarında gerek toplam kelimede gerekse çeşit kelimede paralellik arz eden çalışmalar bulunmakla beraber tam bir birliğe varılmadığı görülmektedir. Çıplak (2005), 5., 8. ve 11. sınıflardan seçtiği 90 öğrenciden oluşan örneklem grubuyla çalışmıştır. Bu araştırmanın kapsamına 
sadece 5. sınıflar girdiğinden çalışmaya yer verilirken örneklem grubu 30 kişi kabul edilmiş ve bu sınıf düzeyinde elde edilen sonuçlara yer verilmiştir.

Yazılı anlatımda aktif kelime hazinesi durumu sosyo-ekonomik düzeye göre incelendiğinde; Çabaz (2007), Başpınar (2008), Turgut Singil (2008) ve Öztekin (2008) araştırmalarının sonucunda orta düzeydeki öğrencilerin daha başarılı olduğu sonucuna ulaşmışlardır. Temur (2006), Hancı (2007) ve Tülü (2012) ise üst düzeydeki öğrencilerin daha başarılı olduğu sonucuna ulaşırken Çıplak (2005), düşük düzeydeki öğrencilerin daha başarılı olduğu sonucuna ulaşmıştır. İncelemeler sırasında sosyoekonomik düzeyin sınıflardaki dağılımının dengeli olmayışı araştırmacıların verilerinde düzeltme işlemine gitmesine yol açmış, sonuç olarak da net bir değerlendirme yapmalarını zorlaştırmıştır. Yazılı anlatımda aktif kelime hazinesi durumu cinsiyete göre incelendiğinde; Çıplak (2005), toplam kelimede kızların, çeşit kelimede ise erkeklerin daha başarılı olduğu sonucuna ulaşmıştır. Temur (2006), Duru (2007), Hancı (2007), Karahan (2007), Başpınar (2008), Turgut Singil (2008), Tülü (2012), Türkyılmaz (2013) hem toplam kelimede hem çeşit kelimede kızların erkeklere göre daha başarılı olduğu sonucuna ulaşırken Çabaz (2007) ve Öztekin (2008) erkeklerin daha başarılı olduğunu tespit etmişlerdir. Yazılı anlatımda aktif kelime hazinesi durumu anlatım türüne göre incelendiğinde ise; ağırlıklı olarak çeşit kelimede anı türünde, toplam kelimede ise serbest konuda yazı yazan öğrencilerin daha başarılı oldukları anlaşılmaktadır.

Temur (2006); kelime sayısının cinsiyete göre değiştiği, gelir düzeyinin kelime sayısını olumlu etkilediği, kardeş sayısı arttıkça kelime sayısının düştüğünü tespit etmiştir. Araştırmaya katılan 4 ve 5. sınıf öğrencilerinin kitap okuma ve gazete okuma sıklığı arttıkça bilgilendirici ve öyküleyici metinlerde kullandıkları toplam ve farkı kelime sayıları artmaktadır. Öğrencilerin günlük ve hikâye türünde yazılar yazması toplam ve farklı kelime sayısındaki artış açısından mektup, şiir ve diğer türlere göre daha etkili olduğu sonucuna da yer verilmiştir.

Cesur (2005), ilköğretim 3-8. sınıf öğrencilerine çocuk edebiyatı kitaplarını okumadan önce ve sonra kompozisyon yazdırılarak durum tespiti yapılmıştır. Araştırma sonuçlarına göre kız öğrenciler hem kelime sayısı bakımından hem de ifadenin düzgünlüğü bakımından daha başarılı olmuştur. Yazanoğlu (2011), ilköğretim 1. sınıf öğrencilerinin kelime dağarcığının gelişmesinde öğrencinin ilk okuma yazma başarısının etkili olduğu ve sosyoekonomik düzeyi iyi olan öğrencilerin daha çok kelime bildiklerini tespit etmiş, cinsiyetin kelime dağarcığında etkili olmadığı sonucuna ulaşmıştır.

Genç (2010), öğrencilerin yeni öğrendikleri kelimeleri kullanım durumlarını tespit etmeyi amaçlamıştır. Araştırma sonucunda öğrencilerin yeni öğrendikleri kelimeleri kullanım durumları oldukça düşük çıkmıştır. Öğrencilerin somut olan kelimeleri yazılı anlatımlarında daha çok kullandıkları ve kız öğrencilerin daha başarılı oldukları görülmüştür. Anılan ve Genç (2011) tarafından yapılan benzer bir çalışma sonucunda da öğrencilerin yeni öğrendikleri kelimeleri kullanım durumları düşük çıkmıştır. 
Karadağ ve Kurudayıoğlu (2010b), ilköğretimdeki her sınıf listesi için kelime sıklık listeleri oluşturmuş, toplam 4000 kelimeyi yapısına göre incelemiş, yapım eki bulunan türemiş kelimeler sınıf seviyelerine göre çıkarılmış ve aldığı eklerin türüne, sayısına, sıklığına ve yüzdeliğine göre çözümlenip yorumlamıştır. Araştırmada, ilköğretimin bütün sınıf düzeylerinde toplam 715 , birbirinden farklı 325 türemiş kelimenin kullanıldığı; 44 farklı yapım ekiyle kelime türetildiği; fiilden isim yapan eklerin toplamda kullanılan yapım eklerinin yarısını karşıladığı ve sayı olarak en az fiilden isim yapan eklerin (2 ek kullanılmıştır) kullanıldığı tespit edilmiştir.

\section{Sözlü Anlatımdaki Aktif Kelime Servetini Belirlemeye Yönelik Çalışmalar}

Türkçe öğretim programında konuşma becerisi ile ilgili olarak öğrencinin konuşmasında söz varlığını kullanması, yeni öğrendiği kelimelere yer vermesi beklenmektedir (MEB, 2009). Bu alanda yapılan bir çalışma tespit edilmiş ve öğrencinin konuşmasında yeni öğrendiği kelimeleri kullanması bu çalışmanın kapsamı içinde yer almamıştır.

Hayriye Ünsal (2005), 5. ve 8. sınıflar ile ortaöğretim 11. sınıfların sözlü anlatımdaki aktif kelime hazinelerini incelemiştir. Araştırma sonucunda sosyoekonomik durumun öğrencilerin kelime hazinesini etkilediği görülmüştür.

\section{Öğretmenler Üzerine Yapılan Çalışmalar}

Çetinkaya, Ateş, Yıldız ve Yıldırım (2010), kelime hazinesini geliştirmek için neler yapılabileceği konusunda sınıf öğretmenlerinin görüşlerine başvurmuşlardır. Araştırma sonucunda genel olarak sınıf öğretmenlerinin kelime hazinesini geliştirme konusunda yetersiz oldukları görülmüştür. Uçar (2012), öğretmenlerin kelime öğretiminden haberdar olup olmadıkları belirlenmeye çalışmıştır. Araştırma sonucunda kadınların erkek öğretmenlere göre daha bilgili oldukları, kıdem yılı az olan öğretmenlerin daha fazla haberdar oldukları görülmüştür.

Yağcl, Katrancı, Erdoğan ve Uygun (2012), sınıf öğretmenlerinin kelime öğretiminde yaşadıkları sorunlar ve kullandıkları yöntem ve teknikleri belirlenmeye çalışmışlardır. Araştırma sonucunda sınıf öğretmenlerinin kelime öğretirken çok çeşitli yöntem ve teknikler kullanmadıkları görülmüştür.

\section{Sonuç ve Öneriler}

Yapılan tarama çalışması sonucunda ilköğretim birinci kademede sözcük öğretimi ile ilgili toplam 62 çalışma tespit edilmiştir. Sözcük öğretiminde esas alınan veriler baz alınarak çalışmalar altı başlık altında sınıflandırılmıştır. Ders kitapları ve metinler üzerine 15 çalışma; uygulamanın esas olduğu 14 çalışma; teorik bilgi veren 13 çalışma; yazılı anlatımdaki aktif kelime servetini belirlemeye 
yönelik 16 çalışma; sözlü anlatımdaki aktif kelime servetini belirlemeye yönelik 1 çalışma; öğretmenler üzerine yapılan 3 çalışma tespit edilmiştir.

2009 İlköğretim Türkçe Dersi 1-5. Sınıflar Öğretim Programında söz varlığı ve kelime hazinesi açısından okuma dosyası başlığı altında çocuk kitaplarında kullanılacak kelimelerin basit, anlamlı, canlı, sonuç bildiren, fark edilen, akılda kolay kalan ve kolay okunan kelimeler olmasına dikkat edilmesi gerektiği vurgulanmıştır (MEB, 2009). 2003-2013 yılları arasında, on yıllık uzun bir süreçte yapılan çalışmalardan anlaşılacağı üzere; sözcük öğretiminde ders kitapları ve metinler önemli bir yer taşımaktadır fakat kitapların içeriği ve metinlerin seçimi konusunda aynı önem görülmemektedir. Türkçe öğretiminin temel materyali olan ders kitaplarına ve metin seçimine yönelik düzenlemelerin yapılması ile sözcük öğretiminde de ilerleme kaydedileceği aşikârdır.

Uygulamanın esas olduğu çalışmalarda araştırmacıların; sosyo-ekonomik durum, cinsiyet ve ailenin eğitim düzeyi gibi değişkenler üzerinde yoğunlaştığı görülmektedir. Teorik bilgi veren çalışmalarda ise; kelime hazinesinin önemi vurgulanmış, sözcük öğretiminde kullanılan teknikler ve uygulanabilecek etkinlikler hakkında bilgi verilmiştir.

Yazılı anlatımdaki aktif kelime servetini belirlemeye yönelik çalışmaların sonucunda; sosyoekonomik düzeyin kelime sayısını olumlu etkilediği ve öğrencilerin yeni öğrendikleri kelimeleri kullanım durumları oldukça düşük olduğu tespit edilmiştir. Çalışmaların çoğunda serbest konu, anı ve otobiyografi türlerinde kompozisyon yazdırılmasına rağmen türler açısından çalışma sonuçlarında bir birlik sağlanamamıştır. Cinsiyet değişkenine göre de çalışmalarda farklı sonuçlar elde edildiği görülmektedir. Sözlü anlatımdaki aktif kelime servetini belirlemeye yönelik sadece bir araştırmaya rastlaşmıştır. Araştırma sonucunda sosyoekonomik durumun öğrencilerin kelime hazinesini etkilediği görülmüştür. Konuşma becerisinin işe koşulmasıyla yapılabilecek sözcük öğretimi çalışmalarının arttırılması gerekmektedir.

Öğretmenler üzerine yapılan çalışmaların sonucunda ise; genel olarak sınıf öğretmenlerinin kelime hazinesini geliştirme konusunda yetersiz oldukları görülmüştür. Kıdem yılı az olan öğretmenlerin durumdan daha fazla haberdar olmaları dikkat çekicidir. Çalışmalar, sınıf öğretmenlerinin kelime öğretirken çok çeşitli yöntem ve teknikler kullanmadıklarını göstermektedir. Bu anlamda öğretmenlerin sözcük öğretimi konusunda bilgilendirilmeleri ve güncel gelişmeleri takip etmeleri sağlanmalıdır.

Yapılan çalışmaların sınıf aralıkları incelendiğinde özellikle yazılı anlatımdaki kelime servetini belirlemeye yönelik çalışmaların sayısının 5. sınıf düzeyinde yoğunlaştığı görülmektedir. İlköğretim birinci kademede farklı sınıf düzeylerine yönelik yazma becerisi ve sözcük öğretimi ile ilgili çalışmalarının arttırılması, hatta sınıf düzeyindeki aşamalııı̆ın sözcük öğretimine, kelime servetine olan katkısının araştırılması önem arz etmektedir. 
Milli Eğitim Bakanlığı Türkçe öğretim programı 1-5.sınıflar (2009) kazanımlarında söz varlığını geliştirmeyle ilgili olarak dinleme alanında; "Dinlediklerinde geçen bilmediği kelimelerin anlamlarını tahmin eder, dinledikleri kelimelerin gerçek ve mecaz anlamlarını, sesteş kelimeleri, eş ve karşıt anlamlı kelimeleri, duygusal ve abartılı sözleri ayırt eder." ifadeleri yer almasına rağmen yapılan çalışmalar incelendiğinde sözcük öğretiminde dinleme becerisine yönelik bir araştırmaya rastlanmamıştır. Okuma alanında da; “Görsellerden yararlanarak söz varlı̆ı̆ı geliştirir, kelimelerin eş ve karşıt anlamlılarını bulur, sesteş kelimelerin anlamlarını ayırt eder, bilmediği kelimelerin anlamlarını araştııır." ifadeleri geçmekle beraber taranan çalışmalarda gerek dinleme gerekse okuma becerisinin sözcük öğretimi ile ilişkilendirildiği bir çalışma da tespit edilememiştir. Araştırmacıların bu beceri alanlarına yoğunlaşması yerinde olacaktır.

\section{Kaynaklar}

Acat, M.B. (2008). Anlamı Bilinmeyen Kelimelerin Öğretiminde Kavram Haritalarının Etkililiği, Eurasian Journal of Educational Research, 33, 1-16.

Akyol, H. (1997). Kelime Öğretimi, Milli Eğitim Dergisi, 134.

Akyol, H. (2006). Türkçe Illk Okuma Yazma Öğretimi. Ankara: Pegem A Yayıncılık.

Akyol, H., ve Temur,T. (2007). Kelime Hazinesinin Gelişstirilmesi, ilköğretimde Türkçe Öğretimi içinde. Ankara: Pegem, 195-232.

Akyüz Aru, S. (2013). Yeni Ilköğretim Programına Göre Hazırlanan Türkçe Ders Kitaplarında Kelime Hazinesini Geliştirmeye Yönelik Planlamanın Incelenmesi. Ankara: Gazi Üniversitesi, Eğitim Bilimleri Enstitüsü, Yayımlanmamış Yüksek Lisans Tezi.

Alpöge,G. (1991). Çocuk ve dil: Türkçede sıfatların kullanımı ve çocuğun gelişimi açısından incelenmesi. Ankara:YKY.

Anılan, H. ve Genç, B. (2011). Türkçe Dersinde Öğrenilen Yeni Sözcüklerin Yazılı Anlatımlarda Kullanım Durumu, Ahi Evran Üniversitesi Eğitim Fakültesi Dergisi, 12(1), 111-132.

Anılan, H., Genç, B., \& Göl Dede, D. (2011). Destekleyici Ek Metin Çalışmalarının Kırsal Kesim Öğrencilerinin Kelime Kazanım Düzeylerine Etkisi, Pamukkale Üniversitesi Eğitim Fakültesi Dergisi, 29,43-57.

Aslan, C. (2006). Türkçe Ders Kitaplarında "Türkçe Olmayan Sözcükler"in Kullanımı Üzerine Bir İnceleme. Dil Dergisi, 133.

Baş, B. (2006). 1985-2005 Yılları Arasında Çocuk Edebiyatı Sahasında Yazıımış Tahkiyeli Metinlerin Söz Varlığı Üzerine Bir Araştırma. Ankara: Gazi Üniversitesi, Eğitim Bilimleri Enstitüsü, Yayımlanmamış Doktora Tezi.

Baş, B. (2010). Söz Varlığı Araştırmalarında Veri Çarpıklığı ve Eğitime Yansımaları, Erzincan Eğitim Fakültesi Dergisi, 12 (2), 115-129. 
Başpınar, O. (2008). Illköğretim 5. Sınıf Öğrencilerinin Aktif Kelime Serveti Üzerine Bir Araştırma (Manisa/Turgutlu ilçesi örneği). Afyonkarahisar: Afyon Kocatepe Üniversitesi, Sosyal Bilimler Enstitüsü, Yayımlanmamış Yüksek Lisans Tezi.

Cesur, O. (2005). (Kastamonu ilinde bir inceleme) Pansiyonlu Illköğretim Okulu Öğrencileri Üzerinde Kelime Serveti Araştırması. Bolu: Abant İzzet Baysal Üniversitesi, Sosyal Bilimler Enstitüsü, Yayımlanmamı̧̧ Yüksek Lisans Tezi.

Çabaz, Y. (2007). Ilköğretim 5. Sınıf Öğrencilerinin Yazılı Anlatımlarındaki Aktif Kelime Servetinin Belirlenmesi (Kırklareli/Merkez Örneği). Afyonkarahisar: Afyon Kocatepe Üniversitesi, Sosyal Bilimler Enstitüsü, Yayımlanmamış Yüksek Lisans Tezi.

Çeçen, M.A. (2002). ilk Öğretim Öğrencilerinde Kelime Hazinesinin Geliştirilmesi. Malatya: İnönü Üniversitesi, Sosyal Bilimler Enstitüsü, Yayımlanmamış Yüksek Lisans Tezi.

Çetinkaya, Ç., Ateş, S., Yıldız, M., \& Yıldırım, K. (2010). İlköğretimde Türkçe Kelime Hazinesini Geliştirmeye Yönelik Sınıf Öğretmenlerinin Görüşleri, Selçuk Üniversitesi Ahmet Keleşoğlu Eğitim Fakültesi Dergisi, 30, 101-109.

Çevik, A. (2011). Ilköğretim ikinci Sınıf Öğrencilerinin Kelime Servetini Zenginleștirme Üzerine Deneysel Bir Çalışma. Kırıkkale: Kırıkkale Üniversitesi, Sosyal Bilimler Enstitüsü, Yayımlanmamış Yüksek Lisans Tezi.

Çıplak, M. (2005). Uşak Merkez Illköğretim 5. 8. ve 11. Sınıfların Yazılı Kelime Hazinesinin Belirlenmesi. Afyonkarahisar: Afyon Kocatepe Üniversitesi, Sosyal Bilimler Enstitüsü, Yayımlanmamış Yüksek Lisans Tezi.

Davaslıgil, Ü. (1985). Farkı Sosyo-Ekonomik ve Kültürel Çevreden Gelen Birinci Sınıf Çocuklarının Dil Gelişiminde Okulun Etkisi. İstanbul: Edebiyat Fakültesi Basımevi.

Demir, C. (2006). Türkçe Eğitimi ve Kişisel Kelime Serveti, Milli Eğitim Dergisi, 169, 207-225.

Duran, E. (2010). 1-5. Sınıflar Öğretim Programında Kelime Hazinesini Geliştirme Uygulamaları, Türkiye Sosyal Araştırmalar Dergisi, 1-20.

Duru, K. (2007). ilköğretim 5. Sınıf Öğrencilerinin Yazılı Anlatımlarındaki Aktif Kelime Servetinin Belirlenmesi (Uşak/Sivası Örneği). Afyonkarahisar: Afyon Kocatepe Üniversitesi, Sosyal Bilimler Enstitüsü, Yayımlanmamış Yüksek Lisans Tezi.

Ergün, M. (2014). Çocukluk Döneminde Bedensel, Bilişsel ve Sosyal Gelişim. İnternetten 15 Mart 2014'te www.egitim.aku.edu.tr/gelisim04.ppt adresinden alınmıştır.

Genç, B. (2010). Türkçe Dersinde Öğrenilen Yeni Sözcüklerin Yazılı Anlatımda Kullanım Durumu. Eskişehir: Eskişehir Osmangazi Üniversitesi, Sosyal Bilimler Enstitüsü, Yayımlanmamış Yüksek Lisans Tezi.

Göçer, A. (2009). Türkçe Eğitiminde Öğrencilerin Söz Varlığını Geliştirme Etkinlikleri ve Sözlük Kullanımı, Turkish Studies, 5(1), 1007-1036.

Güneş, F. (2013). Kelimelerin Gücü ve Zihinsel Sözlük, Siirt Üniversitesi Sosyal Bilimler Enstitüsü Dergisi, 1, 1-24.

Gür, T., Coşkun, İ., \& Sağlam, F. (2013). İlkokul 2, 3 ve 4. Sınıf Türkçe Ders Kitapları Bütüncesinin Kelime Hazinesini Geliştirme Eğitimi Açısından Incelenmesi, Turkish Studies, 8(1). 
Hancı, G. (2007). IIlköğretim 5. Sınıf Öğrencilerinin Yazılı Anlatımlarındaki Aktif Kelime Servetinin Belirlenmesi (Uşak/Banaz Örneği). Afyonkarahisar: Afyon Kocatepe Üniversitesi, Sosyal Bilimler Enstitüsü, Yayımlanmamış Yüksek Lisans Tezi.

Ince, H.G. (2006). Türkçede Kelime Öğretimi. Bolu: Abant İzzet Baysal Üniversitesi, Sosyal Bilimler Enstitüsü, Yayımlanmamış Yüksek Lisans Tezi.

İpek, N. (2006). Ilköğretim Çağı Çocuklarında Kelime Dağarcığı Gelişimi. Bursa: Uludağ Üniversitesi, Sosyal Bilimler Enstitüsü, Yayımlanmamış Yüksek Lisans Tezi.

İpek, N. ve Bilgin, A. (2007). İlköğretim Çağı Çocuklarında Kelime Dağarcığı Gelişimi, ilköğretim Online, 6(3), 344365.

İpek Eğilmez, N. (2010). Illköğretim Türkçe Ders Kitaplarındaki Söz Varlığının İlköğretim Dördüncü Sınıf Öğrencilerinin Yazılı Anlatımlarına Aktarımı. Bursa: Uludağ Üniversitesi, Eğitim Bilimleri Enstitüsü, Yayımlanmamış Doktora Tezi.

Karadağ, Ö. (2005). Ilköğretim 1. Kademe Öğrencilerinin Kelime Hazinesi Üzerine Bir Araştırma. Ankara: Gazi Üniversitesi, Eğitim Bilimleri Enstitüsü, Yayımlanmamış Doktora Tezi.

Karadağ, Ö. (2013). Kelime Öğretimi, İstanbul: Kriter Yayınevi.

Karadağ, Ö. ve Kurudayıoğlu, M. (2010a). 2005 Türkçe Programına Göre Hazırlanmış İlköğretim Birinci Kademe Türkçe Ders Kitaplarının Kelime Hazinesi, TÜBAR, XXVII, 423-436.

Karadağ, Ö. ve Kurudayıoğlu, M. (2010b). Türkçedeki Kelime Türetme Özelliğinin İlköğretim Öğrencilerinin Yazılı Anlatımlarına Yansıması, TÜBAR, XXVII, 437-455.

Karahan, A. (2007). Uşak Ulubet Il/çesi Köy Ilköğretim Okulları 5. Sınıfların Yazılı Anlatımlarındaki Kelime Servetinin Belirlenmesi. Afyonkarahisar: Afyon Kocatepe Üniversitesi, Sosyal Bilimler Enstitüsü, Yayımlanmamış Yüksek Lisans Tezi.

Kazak Berument, S. ve Güven, A.G. (2013). Türkçe Iffade Edici ve Alıcı Dil (TifALDi) Testi: I. Alıcı Dil Kelime Alt Testi Standardizasyon ve Güvenilirlik-Geçerlik Çalışması, Türk Psikiyatri Dergisi, 24.

Keklik, S. (2009).11 Yaşına Kadar Çocukta Dil Edinimi. İstanbul: Marmara Üniversitesi, Eğitim Bilimleri Enstitüsü, Yayımlanmamış Doktora Tezi.

Keklik, S. (2011a). Türkçede 7-11 Yaş Çocuklarına Öğretilmesi Gereken, En Sık Kullanılan 1800 Kelime, Türkiye Sosyal Araştırmalar Dergisi, 2.

Keklik, S. (2011b). Türkçede On Bir Yaşına Kadar Çocuklara Öğretilmesi Gereken Birleşim Gücü Yüksek İlk Bin Kelime, ODÜ Sosyal Bilimler Enstitüsü Sosyal Bilimler Araştırmaları Dergisi, 2 (4).

Keklik, S. (2012). Karşıt Anlamlı Kelimelerin Altı-On Bir Yaş Arası Öğrenciler Tarafından Kavranma Düzeylerinin Bazı Değişkenler Açısından İncelenmesi, Mehmet Akif Ersoy Üniversitesi Sosyal Bilimler Enstitüsü Dergisi , 4(6),70-86.

Lüle Mert, E. (2009). Anadili Eğitimi ve Öğretimi Sürecinde Söz Varlığı Belirleme Çalışmalarının Önemi ve "Deyim" Kazandırmaya Yönelik Etkinlik Önerileri, Adıyaman Üniversitesi Sosyal Bilimler Enstitüsü Dergisi, 2(2),83-93.

Lüle Mert, E. (2010). Etkinliklerle Sözcük Öğretimi. Ankara: Anı Yayıncılık. 
Mangır, M. (2012). İlköğretim 5.Sınıf Türkçe Ders Kitabındaki Deyim Varlığının Öğrencilerin Alıcı Söz Varlığına Katkısı, Turkish Studies, 7(4), 2371-2385.

MEB (2006). Illköğretim Türkçe Dersi Öğretim Programı ve Kılavuzu (1-5. sınıflar). Ankara: Devlet Kitapları Müdürlüğü Basım Evi.

Özalp, B. (2011). Illköğretim 1. ve 2. Sınıf Türkçe Ders Kitaplarındaki Metinlerin Kelime Sayısının Kişisel Kelime Servetine Katkısının Değerlendirilmesi. Konya: Selçuk Üniversitesi, Eğitim Bilimleri Enstitüsü, Yayımlanmamış Yüksek Lisans Tezi.

Özbay, M. ve Melanlıŏlu, D. (2008). Türkçe Eğitiminde Kelime Hazinesinin Önemi, Yüzüncü Yıl Üniversitesi, Eğitim Fakültesi Dergisi, V(I), 30-45.

Özkök Kayhan, E. (2010). Illköğretim Birinci Kademe Çocuklarında Okuduğunu Anlama Ile Sözcük Bilgisi, Görsel Algı ve Kısa Süreli Bellek Arasındaki ilişki. Ankara: Ankara Üniversitesi, Sosyal Bilimler Enstitüsü, Yayımlanmamış Yüksek Lisans Tezi.

Öztekin, M. (2008). Illköğretim 5. Sınıf Öğrencilerinin Aktif Kelime Serveti Üzerine Bir Araştırma (Düzce/Akçakoca Il/çesi Örneği). Afyonkarahisar: Afyon Kocatepe Üniversitesi, Sosyal Bilimler Enstitüsü, Yayımlanmamış Yüksek Lisans Tezi.

Pehlivan, A. (2003). Türkçe Ders Kitaplarında Sözcük Dağarcığını Geliştirme Sorunu ve Çözüm Yolları, Dil Dergisi, $122,84-91$.

Piaget, J.(1969). The Language and Thought of the Child.The World Publishing Company, New York.

Pilancı, H. (2009). 7-9 Yaş Arasındaki Türk Öğrencilerinin Kelime Dağarcığı Gelişimi, Uluslararası Sosyal Araştırmalar Dergisi, 2 (9).

Pilancı, H. (2014). 7-9 Yaş Arasındaki Türk Çocuklarında Kelime Çağrışımını Etkileyen Sosyoekonomik Değişkenler, Bilig, 68, 183-208.

Solmaz, E. (2009). Ilköğretim 4. ve 5. Sınıf Düzeylerindeki Türkçe Metinlerde Cümle Uzunluğu, Kelime Uzunluğu ve Kelime Hazinesinin Okunabilirlik Üzerine Etkisi. Ankara: Gazi Üniversitesi, Eğitim Bilimleri Enstitüsü, Yayımlanmamış Yüksek Lisans Tezi.

Temur,T. (2006). Ilköğretim 4. ve 5. Sınıf Öğrencilerinin Yazı Dilindeki Kelime Hazinelerinin Bazı Değişkenler Açısından incelenmesi. Ankara: Gazi Üniversitesi, Eğitim Bilimleri Enstitüsü, Yayımlanmamış Doktora Tezi.

Tosunoğlu, M. (1999). Kelime Servetinin Eğitim Öğretimdeki Yeri ve Önemi, Millî Eğitim Dergisi, 144.

Tuğyan, Ö. (2010). Bazı Öğretim Materyalleri Kullanımının IIköğretim 2. Sınıf Öğrencilerinin Kelime Servetine Etkisi. Afyonkarahisar: Afyon Kocatepe Üniversitesi, Sosyal Bilimler Enstitüsü, Yayımlanmamış Yüksek Lisans Tezi.

Tuncer, N. (2007). Çocuk Kitaplarında Dil Sorunu, Okuma Kültürü ve Okullarda Uygulama Sorunları. Devlet Kitapları Müdürlüğü.

Turgut Singil,A. (2008). IIlköğretim 3. Sınıf Öğrencilerinin Aktif Kelime Serveti Üzerine Bir Araştırma (Uşak ili Merkez Örneği). Afyonkarahisar: Afyon Kocatepe Üniversitesi, Sosyal Bilimler Enstitüsü, Yayımlanmamış Yüksek Lisans Tezi. 
Tülü, M. (2012). Illköğretim 5. Sınıf Öğrencilerinin Yazılı Anlatımlarındaki Aktif Kelime Serveti Üzerine Bir Araştırma (Uşak/Eşme Örneği). Uşak: Uşak Üniversitesi, Sosyal Bilimler Enstitüsü, Yayımlanmamış Yüksek Lisans Tezi.

Türkyılmaz, M. (2013). Ortaokul 5. Sınıf Öğrencilerinin Yazılı Anlatımdaki Aktif Kelime Hazinesinin Belirlenmesi (Kırşehir/Akçakent Örneği). Ankara: Gazi Üniversitesi, Eğitim Bilimleri Enstitüsü, Yayımlanmamış Yüksek Lisans Tezi.

Uçar, S. (2012). Ilköğretim Sınıf Öğretmenlerinin Kelime Öğretiminde Kullanılan Yöntem ve Tekniklerden Haberdar Olma ve Kullanma Sıkık Düzeyleri. Uşak: Uşak Üniversitesi, Sosyal Bilimler Enstitüsü, Yayımlanmamış Yüksek Lisans Tezi.

Ünsal, H. (2005). 5.ve 8. Sınıflar ile Ortaöğretim 11. Sınıfların Sözlü Anlatımdaki Aktif Kelime Hazineleri. Afyonkarahisar: Afyon Kocatepe Üniversitesi, Sosyal Bilimler Enstitüsü, Yayımlanmamış Yüksek Lisans Tezi.

Yağcı, E., Katrancı, M., Erdoğan Ö., Uygun M. (2012). Sınıf Öğretmenlerinin Kelime Öğretiminde Karşılaştıkları Sorunlar ve Kullandıkları Yöntem-Teknikler, Uluslar arası Eğitim Programları ve Öğretim Çalışmaları Dergisi, 2 (4),1-12.

Yalçın, S. K. (2005). Illköğretim 1. ve 5. Sınıf Türkçe Ders Kitaplarındaki Söz Varlığı Unsurlarının Eğitsel Açıdan Değerlendirilmesi. Elazığ: Fırat Üniversitesi, Sosyal Bilimler Enstitüsü, Yayımlanmamış Yüksek Lisans Tezi.

Yapıcı, Ş. (2004). Çocukta Dil Gelişimi,Uluslararası Insan Bilimleri Dergisi. Internetten 15 Mart 2014'te insanbilimleri.com/makaleler adresinden alınmıştır.

Yazanoğlu, G. (2011). Illköğretim Birinci Sınıf Öğrencilerinde Kelime Dağarcığı Gelişiminin Illkokuma Yazma Başarısı Ve Sosyoekonomik Düzey ile ilişskisi (Şırnak ili Örneği). Bursa: Uludağ Üniversitesi, Sosyal Bilimler Enstitüsü,Yayımlanmamış Yüksek Lisans Tezi.

Yıldıım, A. ve Şimşek, H. (2011). Sosyal Bilimlerde Nitel Araştırma Yöntemleri. Ankara: Seçkin Yayıncılık. 